\title{
Assessment of Heavy Metal Pollution in a Gold Mining Site in Southwestern Nigeria
}

\author{
Abiya SE, Odiyi BO, Ologundudu FA*, Akinnifesi OJ and Akadiri S \\ Department of Biology, Akure, Nigeria \\ *Corresponding author: Ologundudu FA, Department of Biology, Akure, Nigeria
}

Submission: December 05, 2018; Published: February 01, 2019

\begin{abstract}
The unwanted release of environmental contaminants predisposed by mining activities had reached an alarming proportion that deserves attention. Hence, the purpose of this study was to determine the degree of heavy metal contamination which soil and plants were exposed to in Ijana gold mining site, southwestern Nigeria. To this, Zinc, Arsenic, Cadmium, Lead, Nickel, Chromium, and Copper concentrations were measured using Atomic Absorption Spectrometry. Obtained values were used to evaluate the degree of soil pollution and plant contamination using physicochemical analysis, bioaccumulation factor and translocation factor of metals into plant in surrounding mine site. Zinc and Lead show a slightly higher presence than other metals tested. Mean concentrations of $\mathrm{Zn}(0.70 \mathrm{mg} / \mathrm{kg}), \mathrm{As}(0.09 \mathrm{mg} / \mathrm{kg}), \mathrm{Cd}(0.13 \mathrm{mg} / \mathrm{kg}), \mathrm{Pb}(0.216 \mathrm{~kg} / \mathrm{mg}), \mathrm{Ni}(0.08 \mathrm{mg} / \mathrm{kg}), \mathrm{Cr}(0.148 \mathrm{mg} /$ $\mathrm{kg}), \mathrm{Cu}(0.629 \mathrm{mg} / \mathrm{kg})$ in soils around the mining area wereconsiderably the same with the concentration of metal accumulated in plant respectively. All metal tested showed minimal accumulation in plants. Translocation factor also implicated $\mathrm{Zn}$ to be the highest among all the heavy metals analyzed.
\end{abstract}

Keywords: Bioaccumulation; Translocation; Pollution; Tailings

\section{Introduction}

Amongst many anthropogenic activities, mining has been identified with the potential of impacting negatively on the quality of the environment [1,2]. Mining causes the destruction of natural ecosystems by altering soil, vegetative covers and covering of organisms beneath excavation sites. Aside the physical habitat destruction with accompanying the loss of biodiversity resources, the accumulation of pollutants in different media have been recorded around mining sites [3]. Therefore, mining sites portend great toxicological challenges for the surrounding ecosystems and on human health [4]. Like any exploitative activity, the excavation of mineral resources produces negative impacts upon the hydrosphere, atmospheric and lithospheric components of the environment $[5,6]$. In gold mining, like many metallurgical extractions, crystallographic bonds are broken in the ore mineral in order to recover the desired element or compound [7]. During gold mining, large quantities of waste are produced. Over $99 \%$ of extracted ore in gold mining are released into the surrounding environment as waste [8].

One of the wastes that have been implicated around mining sites is heavy metals. Heavy metals have received global attention of researchers, owing to their deleterious effects on plants, especially those on vegetative and generative plant parts. [9]. Due to variations in the physical and chemical properties of soil, heavy metals in tailings can be translocated and accumulated in plants and animals. Even in low concentration, heavy metals can persist in soil from and can enter into food chain through plant uptake [1]. Some heavy metals like Lead, Arsenic, Mercury, Canadium, are not essential for plants growth, since they are not known to perform any physiological function in plants. Other metals like, Iron, Copper, Nickel Manganese, Cobalt, Molybdenum, and Zinc are essential elements required for normal plant growth and metabolism, but when they are above desired concentrations, could constitute poisoning to individual plants $[10,11]$. Among all the heavy metals, cadmium (Cd) is a highly toxic metal for both the plants and animals as well as for human beings. Cadmium enters into soilplant environment mainly through anthropogenic activities.

Elevated $\mathrm{Pb}$ in soils may decrease soil productivity and if in very low concentrations, $\mathrm{Pb}$ may also inhibit some important plant processes i.e. photosynthesis, mitosis, water absorption and vegetative growth [12]. Studies have also shown the genotoxic effect of chromium on cells. $\mathrm{Cr}$ (VI) has been found to 100 times more toxic and 1000 times more mutagenic and carcinogenic compared to $\mathrm{Cr}$ (III) [13]. Heavy metals also exert toxic effects on soil microorganism hence results in the change of the diversity, population size and overall activity of the soil microbial communities [14]. In order to evaluate the damages that gold mining activities exert on the environment, especially in areas in which crude methods of mining is still largely used, there lies the need to assess the extents of pollution. These must be based on studies about waste properties, heavy metals content and their relation to soil and plant. Hence, the objective of this study is to

A. Determine the physicochemical properties of soil from Ijana goldmine. 
B. Determine the concentration of heavy metals found in soils and plants at the goldmine.

C. Compare the result of the physicochemical properties of the soil and heavy metal concentration in plants and soils at Ijana goldmine with that of a control site.

\section{Materials and Methods}

\section{Sampling location}

The study was conducted in a gold mining site in Ilesha, Osun state. The site is located at Ijana of Atakunmosa west local government in Osun state. Mining site is on Latitude $7.573^{\circ} \mathrm{N}$ and longitude $4.678{ }^{\circ} \mathrm{E}$ and the control site on Latitude $7.578{ }^{\circ} \mathrm{N}$ and longitude $4.679^{\circ} \mathrm{E}$.

\section{Soil and plant samples pre-treatment}

Soil and Plant samples were randomly collected at Ijana goldmine site. Control samples were taken at a site a few kilometers away from the mine site. The control sites have no record of mining activities and also have limited human interference. Three soil samples were collected at the surface $(0-15 \mathrm{~cm})$ and subsurface $(15-30 \mathrm{~cm})$ respectively using a hand trowel and meter rule at both mine and control sites. Plant samples (Chromolena odorata) which was common to both the mine and control sites were carefully uprooted ensuring that the roots remained intact. Both the soil and plant samples were correctly labeled and bagged before taking to the laboratory for analysis. Each soil sample was air-dried for 7 days and sieved to $<2 \mathrm{~mm}$ prior to analysis. for physico-chemical properties including $\mathrm{pH}$, potassium $(\mathrm{K})$, calcium $(\mathrm{Ca})$, magnesium $(\mathrm{Mg})$, sodium $(\mathrm{Na}), \mathrm{CaCO}_{3}$, organic matter, total organic, heavy metals. Total $\mathrm{K}, \mathrm{Ca}, \mathrm{Na}$ and $\mathrm{Mg}$ concentrations were determined using flame emission after digestion of the composite samples with boiling $2 \mathrm{MHNO}_{3}$ for $2 \mathrm{~h}$. Porosity and Bulk density, Organic matter contents and other soil and plant analyses were tested using standard methods.

\section{Soil and the plant analyses}

The $\mathrm{pH}$ and conductivity of soil and plant material were carried out using standard methods as described by [15]. The porosity and bulk density of soil samples in mining site and control site were tested using the methods of [16]. Calcium and magnesium (Exchangeable bases) content of soil were assayed following standard methods. The organic composition of the soil was tested using the Walkley-Black Wet oxidation method [17]. The cation exchange capacity was determined using the ammonium saturation method. Bioaccumulation factor of metal concentrations in the receiving plant shoot and were evaluated with concentration in the soil under standard methods of [18] and the formula is shown below.

$$
\text { Bioaccumulation Factor }(B A F)=\frac{\text { metal content in plain shoot }\left(\frac{m g}{k g}\right)}{\text { metal content in soil }\left(\frac{m g}{\mathrm{~kg}}\right)}
$$

Also, the concentrations of metal translocated from root to shoot of the plant around tested site were determined according to the method of [11] and the formula is shown below

$$
T F=\frac{\text { Concentration of metals }\left(\frac{m g}{k g}\right) \text { in the receiving level(shoot) }}{\text { Concentration of metals }\left(\frac{m g}{k g}\right) \text { in the source level }(\text { root })}
$$

\section{Metal analysis}

The metal analyses of samples ( $\mathrm{Ni}, \mathrm{Cd}, \mathrm{As}, \mathrm{Cu}, \mathrm{Zn}, \mathrm{Pb}$ and $\mathrm{Cr}$ ) were carried out by using an Atomic Absorption Spectrophotometer (AAS).

\section{Result and Discussion}

The result of the study carried out on both soil and plants are presented below (Table 1).

Table 1: Physico-chemical properties of soil.

\begin{tabular}{|c|c|c|c|c|}
\hline \multirow{2}{*}{ Soil Parameters } & \multicolumn{2}{|c|}{$\begin{array}{c}\text { (0-15cm Deep) } \\
\text { (15-30cm Deep) }\end{array}$} \\
\cline { 2 - 5 } & $\begin{array}{c}\text { Mining } \\
\text { site }\end{array}$ & Control & $\begin{array}{c}\text { Mining } \\
\text { site }\end{array}$ & Control \\
\hline $\mathrm{pH}$ & 5.91 & 6.85 & 6.92 & 6.94 \\
\hline Conductivity $(\mu \mathrm{s} / \mathrm{cm})$ & 574 & 142 & 1180.33 & 135.33 \\
\hline Porosity $\left(\mathrm{g} / \mathrm{cm}^{3}\right)$ & 43.64 & 51.6 & 47.2 & 51.6 \\
\hline Bulk Density $\left(\mathrm{g} / \mathrm{cm}^{3}\right)$ & 1.41 & 1.21 & 1.32 & 1.21 \\
\hline Sodium $(\mathrm{cmol} / \mathrm{kg})$ & 5.26 & 2.96 & 4.87 & 4.04 \\
\hline Phosphorus $(\mathrm{mg} / \mathrm{kg})$ & 2.22 & 2.13 & 2.56 & 1.78 \\
\hline Potassium $(\mathrm{cmol} / \mathrm{kg})$ & 4.22 & 2.72 & 16.26 & 2.62 \\
\hline Calcium $(\mathrm{cmol} / \mathrm{kg})$ & 1.21 & 1.62 & 2.65 & 2.14 \\
\hline Magnesium $(\mathrm{cmol} / \mathrm{kg})$ & 1.36 & 1.22 & 1.44 & 1.43 \\
\hline CEC (cmol/kg) & 3.12 & 3.22 & 3.26 & 3.15 \\
\hline Organic carbon $(\%)$ & 0.77 & 2.62 & 0.3 & 1.65 \\
\hline Nitrogen $(\%)$ & 0.36 & 0.91 & 1.27 & 0.83 \\
\hline
\end{tabular}

\section{Soil physico-chemical properties}

For the soil physico-chemical properties, the $\mathrm{pH}$ of both the mining and control sites for surface $(0-15 \mathrm{~cm}$ deep) and subsurface (15-30cm deep) level are approximately neutral and within minimum acceptable limits. However, the $\mathrm{pH}$ of the mine site soil at $0-15 \mathrm{~cm}$ was found to be slightly acidic (5.91) than the control (6.85). Also, soil sample at the subsurface $(15-30 \mathrm{~cm})$ level were generally less acidic (Table 1). Effects of such decrease in soil $\mathrm{pH}$ is reported to result in an increase in heavy metal absorption by plants due to dissolution of metal carbonate complexes releasing metals into solution during the rainy season [19]. In the mine soils, soil conductivity was found to be higher than the control soils both at the surface and subsurface levels. At $0-15 \mathrm{~cm}$ (surface layer), the mining site gives a mean value of 574 as against the control site 142. At the sub-surface layer, the mining site gives a mean value of 1180.33 against the control site 135.33 (Table 1). Conductivity at the control site falls within [20] permissible limit of 16-175, that of mine site far exceeds this limit. Conductivity at the mine site was found to be significantly different when compared to that of the control at the surface level $(0-15 \mathrm{~cm})$.

This is probably due to the release of ions which ordinarily will be bound to rocks but are broken down and washed off during the gold mining process. These results conform to the findings by [21] 
in his studies of mine soils. The mean value for the bulk density of the soil surface level of the mining site was found to be 1.41 and control 1.21 while the bulk density of the soil sub-surface level of the mining site was found to be 1.32 and control 1.21. With respect to physicochemical analyses carried, only bulk density and calcium has significant difference across the two surface levels.

\section{Heavy metals concentration in soil}

The highest levels of $\mathrm{Zn}, \mathrm{Cd}, \mathrm{Pb}$, and $\mathrm{Cu}$ were found in the soil from mine site (Table 2). The levels of $\mathrm{Zn}$ were lower than the range expected in contaminated soils i.e. $20-300 \mathrm{mg} / \mathrm{kg}$. The levels of $\mathrm{Ni}$ found in the soil samples were also below the normal range of $1-110 \mathrm{mg} / \mathrm{kg}$ reported for uncontaminated soils. For both surface and subsurface soil in the mine and control sites, arsenic was found to be the element with the least concentration. The concentrations of all metal recorded in the two surfaces are not too different from one another. Soil samples collected top surface $(0-15 \mathrm{~cm}$ deep) had slightly lower levels of $\mathrm{Pb}$ than the normal than the sub-surface (15-30cm deep). The copper, chromium and arsenic concentrations were, however, lower than the values reported for typical uncontaminated soil. This result conforms to the findings of [15]. A high contamination of the soil with metal could elicit deleterious effects on microbial activities, [22] provoking a low organic matter mineralization needed for plant growth. The apparent increase of heavy metals concentration in mine site compared to the control site almost certainly confirms the mining waste as the potential source of soil contamination and their accumulation in plants. An increasing level of these metals presents the site as potentially hazardous and could alter food chain and biological life in the environment.

\section{Heavy metal concentrations in plant}

In the present study, the results obtained showed that heavy metal $(\mathrm{Zn}, \mathrm{As}, \mathrm{Cd}, \mathrm{Pb}, \mathrm{Ni}, \mathrm{Cr}$ and $\mathrm{Cu}$ ) concentrations varied in the plants parts. In both the root and shoot, the concentrations of heavy metals were found to be higher in the mine site than the control site (Table 3). Of all the level of heavy metal concentrations, Zinc and Lead shows to be significantly higher in the mine site when compared to the control.

Zinc as a natural soil element play essential functional and structural role in plant growth. It usually occurs in low concentrations and does not pose a toxicity problem for plants, but at higher concentration could pose some risk on plants [23,24]. In Table 3, the values of zinc in both root $(1.205 \mathrm{mg} / \mathrm{kg})$ and shoot $(1.017 \mathrm{mg} / \mathrm{kg})$, though higher in mine site than the control is much lower compared to environmental quality standard range of 100 $400 \mathrm{mg} / \mathrm{kg}$.

Reports from various studies have implicated lead accumulation in vegetative plant part declining with distance from possible contamination sites [25]. This is also noticed in the present study. The rate of deposition of lead on vegetative cover is about four times greater than on bare soil. [26]. In the present study the lead concentration recorded in the two plant parts was quite low compared environmental quality standard range of $50 \mathrm{mg} / \mathrm{kg}$.
Arsenic tested in plants is below the toxicity threshold for above ground tissues of $3-10 \mathrm{mg} / \mathrm{kg}$.

Nickel play vital metabolic function in higher plants, the value of nickel in study root and shoot: was 0.079 and $0.088 \mathrm{mg} /$ $\mathrm{kg}$, respectively. These values of nickel were quite lower than environmentally acceptable standard of $1-5 \mathrm{mg} / \mathrm{kg}$. [23]. Naturally without pollution, the copper concentration in soil is $20 \mathrm{ppm}$. In this study, Copper concentrations in plants species were not higher than the toxic values. The little concentration recorded might be due to the presence of copper in minerals which can be released only by very slow disintegration processes [18]. Cadmium is a nonessential nutrient; the value of $\mathrm{Cd}$ is recorded in both plant and shoot is equally low. Compared with the other metal's cadmium is found to leach more in soil, with increased availability in plant [23]. It has also been found that cadmium pollution without cocontamination by zinc is rare. [27]. Although all metals assayed were still within the permissible limit, the presence of metal tends to be higher in the root part than in the shoot. And also higher in the mine site than in the control (Table 2-5).

Table 2: Heavy metals concentration in soil.

\begin{tabular}{|c|c|c|c|c|}
\hline \multirow{2}{*}{ Elements } & \multicolumn{2}{|c|}{ (0-15cm Deep) } & \multicolumn{2}{c|}{ (15-30cm Deep) } \\
\cline { 2 - 5 } & Mining site & Control & Mining site & Control \\
\hline $\mathrm{Zn}$ & 0.7 & 0.628 & 0.628 & 0.614 \\
\hline $\mathrm{As}$ & 0.09 & 0.05 & 0.051 & 0.049 \\
\hline $\mathrm{Cd}$ & 0.13 & 0.05 & 0.09 & 0.019 \\
\hline $\mathrm{Pb}$ & 0.216 & 0.206 & 0.278 & 0.267 \\
\hline $\mathrm{Ni}$ & 0.08 & 0.072 & 0.081 & 0.071 \\
\hline $\mathrm{Cr}$ & 0.148 & 0.125 & 0.14 & 0.128 \\
\hline $\mathrm{Cu}$ & 0.629 & 0.48 & 0.629 & 0.602 \\
\hline
\end{tabular}

Table 3: Heavy metals concentration in plant.

\begin{tabular}{|c|c|c|c|c|}
\hline \multirow{2}{*}{ Elements } & \multicolumn{2}{|c|}{ Root } & \multicolumn{2}{c|}{ Shoot } \\
\cline { 2 - 5 } & Mining site & Control & Mining site & Control \\
\hline $\mathrm{Zn}$ & $1.205^{*}$ & 0.412 & $1.017^{*}$ & 0.3 \\
\hline $\mathrm{As}$ & 0.003 & 0.002 & 0.005 & 0.003 \\
\hline $\mathrm{Cd}$ & 0.015 & 0.003 & 0.007 & 0.002 \\
\hline $\mathrm{Pb}$ & 0.202 & 0.12 & 0.134 & 0.089 \\
\hline $\mathrm{Ni}$ & 0.079 & 0.06 & 0.088 & 0.065 \\
\hline $\mathrm{Cr}$ & 0.119 & 0.007 & 0.124 & 0.008 \\
\hline $\mathrm{Cu}$ & 0.602 & 0.47 & 0.59 & 0.512 \\
\hline
\end{tabular}

Table 4: Translocation factor in plant.

\begin{tabular}{|c|c|c|c|c|c|c|c|}
\hline SITES & $\mathbf{T F}^{\mathbf{Z n}}$ & $\mathbf{T F}^{\text {As }}$ & $\mathbf{T F}^{\mathbf{C d}}$ & $\mathbf{T F}^{\mathbf{P b}}$ & $\mathbf{T F}^{\mathbf{N i}}$ & $\mathbf{T F}^{\mathbf{C r}}$ & $\mathbf{T F}^{\mathbf{C u}}$ \\
\hline Mining & 0.96 & 0.7 & 0.83 & 0.74 & 0.22 & 0.69 & 0.95 \\
\hline Control & 0.72 & 0.33 & 0.4 & 0.65 & 0.68 & 0.53 & 0.84 \\
\hline
\end{tabular}

Table 5: bioaccumulation factor in plant.

\begin{tabular}{|c|c|c|c|c|c|c|c|}
\hline SITES & $\mathbf{B A F}^{\mathbf{Z n}}$ & $\mathbf{B A F}^{\mathbf{A s}}$ & $\mathbf{B A F}^{\mathbf{C d}}$ & $\mathbf{B A F}^{\mathbf{P b}}$ & $\mathbf{B A F}^{\mathbf{N i}}$ & $\mathbf{B A F}^{\mathbf{C r}}$ & $\mathbf{B A F}^{\mathbf{C u}}$ \\
\hline Mining & $1.65^{*}$ & 0.1 & 0.58 & 0.37 & 0.87 & 0.63 & 0.97 \\
\hline Control & 0.26 & 0 & 0.01 & 0.17 & 0.06 & 0.14 & 0.67 \\
\hline
\end{tabular}

*= Significant 


\section{Heavy metals translocation in plant}

Translocation factor was calculated as the ratio of heavy-metal concentrations in plant shoot to those in the corresponding root. According to the previous research results [28], TF value should be below 1 ( $\mathrm{TF}>1)$. This study shows the results of Translocation Factor (TF) of heavy metals from shoot to root. From the result in Table 4, Zn was found to have the highest translocation factor in C. odorata at the mine site, followed by $\mathrm{Cu}$. For both metals, the translocation factor is less than 1. (0.96 at the mine site against 0.72 at the control site and 0.95 for $\mathrm{Cu}$ at the mine site against 0.85 at the control site). This implies that the shoot of this plant hold these metals than others. Therefore, the order of uptake capability from shoot to root is $\mathrm{Zn}>\mathrm{Cu}>\mathrm{Cd}>\mathrm{Pb}>\mathrm{As}>\mathrm{Ni}$.

\section{Heavy metal bioaccumulation in plant}

Bioaccumulation factor (BAF), calculated as the ratio of heavymetal concentrations in plant shoot to those in the corresponding soil. According to [29] BAF value should be below 1 . In this study only Zinc had a $B A F>1$, other metals are generally less than 1 . This result indicates that the concentration of $\mathrm{Zn}$ in the plant shoot is higher than that in soil. Zinc has been confirmed to be easily absorbed by plants [30]. At the control site, none of the heavy metals had a bioaccumulation factor of more than 1 . Copper was the highest at 0.67. $\mathrm{Zn}, \mathrm{As}, \mathrm{Cd}, \mathrm{Pb}, \mathrm{Ni}, \mathrm{Cr}$ and $\mathrm{Cu}$ had bioaccumulation factor 0.01 , $0.01,0.17,0.06,0.14$ and 0.67 respectively (Table 5).

\section{Conclusion}

The concentration levels of heavy of metals ( $\mathrm{Zn}, \mathrm{As}, \mathrm{Cd}, \mathrm{Pb}, \mathrm{Ni}, \mathrm{Cr}$ and $\mathrm{Cu}$ ) in the soil and plants samples from Ijana mining site were generally low and found to be within the World Health Organization (WHO) permissible levels. This could probably be due to the fact that most mining operations in the site are low scale and artisanal in operation unlike other sites where mechanized mining techniques could predispose release of more pollutants and tailings. Therefore, the soils at Ijana at the time of this study doesn't present significant contaminations, thus the soil environment around the mining field are yet to be impacted negatively by the mining activity. Increased mine expansion would also necessitate continued assessment for possible pollution around the mine site.

\section{References}

1. Donkor AK, Bonzongo JCJ, Nartey VK, Adotey DK (2005) Heavy metals in sediments of the gold mining impacted PRA River basin, Ghana, West Africa, Soil and Sediment Contamination 14(6): 479-503.

2. Acosta JA, Faz A, Martínez MS, Zornoza R, Carmona DM, et al. (2011) Multivariate statistical and g is-based approach to evaluate heavy metals behavior in mine sites for future reclamation. J Geochemical Explor 109(1-3): 8-17

3. Getaneh W, Alemayehu T (2006) Metal contamination of the environment by placer and primary gold mining in the Adola region of southern Ethiopia. Environ Geol 50(3): 339-352.

4. Hernández MO, Vásquez MMS, Patiño SA, Dendooven L (2010) Heavy metals concentration in plants growing on mine tailings in Central Mexico. Bioresource Technol 101(11): 3864-3869.
5. Eisler R (2004) Arsenic hazards to humans, plants, and animals from gold mining. Rev Environ Contam Toxicol 180: 133-165.

6. González I, Jordán MM, Sanfeliu T, Quiroz M, De La FC (2007) Mineralogy and heavy metal content in sediments from Rio Gato, Carelmapu and Cucao, Southern Chile. Environ Geol 52(7), 1243-1251.

7. Lottermoser B (2007) Mine Wastes: Characterization, Treatment and Environmental Impacts. Springer, New York, USA, pp. 1-290.

8. Adler R, Rascher JA (2007) Strategy for the management of acid mine drainage from gold mines in Gauteng. CSIR, Pretoria, South Africa.

9. Ekaterina AJ, Craker LE (2001) Heavy metals and seed germination in some medicinal and aromatic plants. Journal of Herbs, Spices \& Medicinal Plants 10(2): 105-112.

10. Garrido S, Campo GMD, Esteller MV, Vaca R, Lugo J (2002) Heavy metals in soil treated with sewage sludge composting, their effect on yield and uptake of broad bean seeds (Vicia faba L.). Water, Air, and Soil Pollution 166: 303-319.

11. Rascio N, Izzo FN (2011) Heavy metal hyperaccumulating plants: How and why do they do it? And what makes them so interesting? Plant Science 180(2): 169-181.

12. Bhattacharyya P, Chakrabarti K, Chakraborty A, Tripathy S, Powell MA (2008) Fractionation and bioavailability of $\mathrm{Pb}$ in municipal solid waste compost and $\mathrm{Pb}$ uptake by rice straw and grain under submerged condition in amended soil. Geosciences Journal 12(1): 41-45.

13. Costa M (2003) Potential hazards of hexavalent chromate in our drinking water. Toxicol Appl Pharmacol 188(1): 1-5.

14. Ashraf R, Ali TA (2007) Effect of heavy metals on soil microbial community and mung beans seed germination. Pakistan Journals of Botany 39(2): 629-636.

15. Tahar K, Keltoum B (2011) Effects of heavy metals pollution in soil and plant in the industrial area, West Algeria. Journal of the Korean Chemical Society 55(6): 1018-1023.

16. Danielson RE, Sutherland PL (1986) Porosity, in methods of soil analysis part 1. Physical and Mineralogical Methods, Agronomy Monograph Soil Science Society of America, Madison, USA, pp. 443-461

17. Walkley A, Black IA (1934) An examination of Degtjareff method for determining soil organic matter and a proposed modification of the chromic acid titration method. Soil Sci 37: 29-37.

18. Radulescu C, Stihi L, Barbes A, Chilian ED (2013) Studies concerning heavy metals accumulation of Carduus nutans L. and Taraxacum officinale as potential soil bioindicator species. Revista de Chimie 64(7): 212-250.

19. Mapanda F, Mangwayana EN, Nyamongara JG, Giller KE (2004) The effects of long-term irrigation using waste water on heavy metal contents of soil and vegetables in Harare, Zimbabwe. Agric ecosystem and environ 107(2-3): 151-165.

20. WHO (1996) Permissible limits of heavy metals in soil and plants. World Health Organization, Geneva, Switzerland.

21. Bjuhr J (2007) Trace metals in soils irrigated with waste water in a periurban area downstream. Hanoi City, Vietnam.

22. Dai J, Becquer T, Rouiller JH, Reversat G, Reversat, et al. (2004) Influence of heavy metals on $\mathrm{C}$ and $\mathrm{N}$ mineralisation and microbial biomass in $\mathrm{Zn}$ Pb-, Cu-, and Cd-contaminated soils. Applied Soil Ecology 25(2): 99-109.

23. Ahmad SS, Erum S (2010) Integrated assessment of heavy metals pollution along motorway M-2. Soil and Environment 29(2): 110-116.

24. Paschke MW, Redente EF, Levy DB (2000) Environmental Toxicity and Chemistry 19: 2751.

25. Little PE (1995) Environmental and Medical Services Division. AERE Didcot, Oxford Shire, UK. 
26. Little P, Wiffenn RD (1978) Atmos Environ 12: 1331.

27. Clemente R, Paredes C, Bernal MP (2007) A field experiment investigating the effects of olive husk and cow manure on heavy metal availability in a contaminated calcareous soil from Murcia (Spain). Agriculture Ecosystems and Environment 118(1-4): 319-326.

28. Baker AJM, Brooks RR (1989) Terrestrials higher plants which hyper accumulate metallic elements. A review of their distribution, ecology and phytochemistry. Bio recovery 1: 81-26.
29. Gautam P, Blaha U, Appel E (2005) Integration of magnetism and heavy metal chemistry of soils to quantify the environmental pollution in Kathmandu, Nepal. Island Arc 14(4): 424435.

30. Mijovilovich A, Leitenmaier B, Meyer KW, Kroneck PM, Gotz B, et al. (2009) Complexation and toxicity of copper in higher plants. II. Different mechanisms for copper versus cadmium detoxification in the coppersensitive cadmium/zinc hyperaccumulator Thlaspi caerulescens (Ganges Ecotype). Plant Physiol 151: 715-731. (c) (i) Creative Commons Attribution 4.0 International License

For possible submissions Click Here
Submit Article

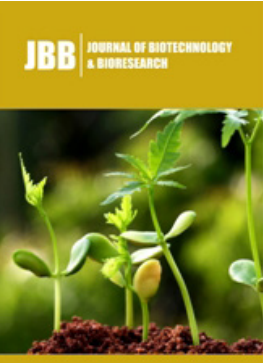

\section{Journal of Biotechnology \& Bioresearch}

\section{Benefits of Publishing with us}

- High-level peer review and editorial services

- Freely accessible online immediately upon publication

- Authors retain the copyright to their work

- Licensing it under a Creative Commons license

- Visibility through different online platforms 